\title{
Nitroalkanes as key building blocks for the synthesis of heterocyclic derivatives
}

\author{
Roberto Ballini* and Marino Petrini \\ Dipartimento di Scienze Chimiche, Università di Camerino, via S. Agostino, 1, \\ I-62032 Camerino, Italy \\ E-mail: roberto.ballini@unicam.it
}

\begin{abstract}
Nitroalkanes constitute a valuable source of stabilized carbanions for carbon-carbon bond formation through reaction with suitable electrophiles. Reduction of the nitro group or its conversion to a carbonyl group readily provides the necessary amino and oxygenated functions suitable for the preparation of various heterocyclic derivatives.
\end{abstract}

Keywords: Conjugate addition, heterocycles, Nef reaction, nitro-aldol reaction, nitro-alkanes

\section{Contents}

1. Introduction

2. Lactones

$2.1 \gamma$ - Lactones

2.2 Macrolactones and dilactones

3. Spiroketals

4. Pyrrolidines and derivatives

4.1 Pyrrolidin-2-ones

4.2 Pyrrolidines and related bicyclic derivatives

5. Piperidines and related derivatives

6. Polyheterocyclic derivatives

7. Conclusions

\section{Introduction}

Cyclic frameworks incorporating one or more heteroatoms in their structures are included in a considerable number of compounds which are of practical interest. The nature of the functional 
groups present in the reactants used for their preparation depends strongly on the attributes of the heterocyclic system. The preparation of oxygen- containing rings usually requires the presence of hydroxy groups in some key step of their synthesis. Similarly, the introduction of nitrogen atoms in cyclic structures can be realized by starting from amino compounds that can, in turn, be obtained by reduction of various nitrogenated derivatives. In this context, nitroalkanes, $\mathbf{1}$, are versatile intermediates since their reduction provides a straightforward entry to amino derivatives, 2 (Scheme 1). ${ }^{1,2}$ Furthermore, the nitro- to carbonyl conversion, also known as the Nef reaction, allows the introduction of an important functional group that, by means of nucleophilic addition or reduction processes, readily affords the hydroxy functionality. ${ }^{3}$

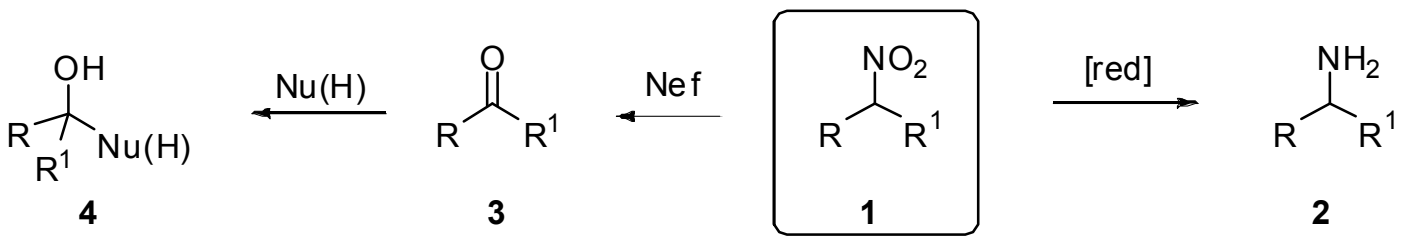

\section{Scheme 1}

From a synthetic standpoint, the transformations cited above usually occur at a stage of the overall process when the assembling of the molecular structure is rather advanced. Therefore, nitro compounds would not be particularly useful if they were not able to assist the carboncarbon bond formation. Fortunately, nitroalkanes also represent a formidable source of stabilized carbanions since the high electron- withdrawing power of the nitro group provides an outstanding enhancement of the hydrogen acidity at the $\alpha$ - position. ${ }^{4}$ Base- treatment of the nitroalkanes 5 produces the corresponding nitronate anions $\mathbf{6}$ which can be used as carbon nucleophiles in reactions with haloalkanes, ${ }^{5}$ aldehydes, ${ }^{6,7}$ and Michael acceptors, leading to adducts 7-9 (Scheme 2). ${ }^{8}$

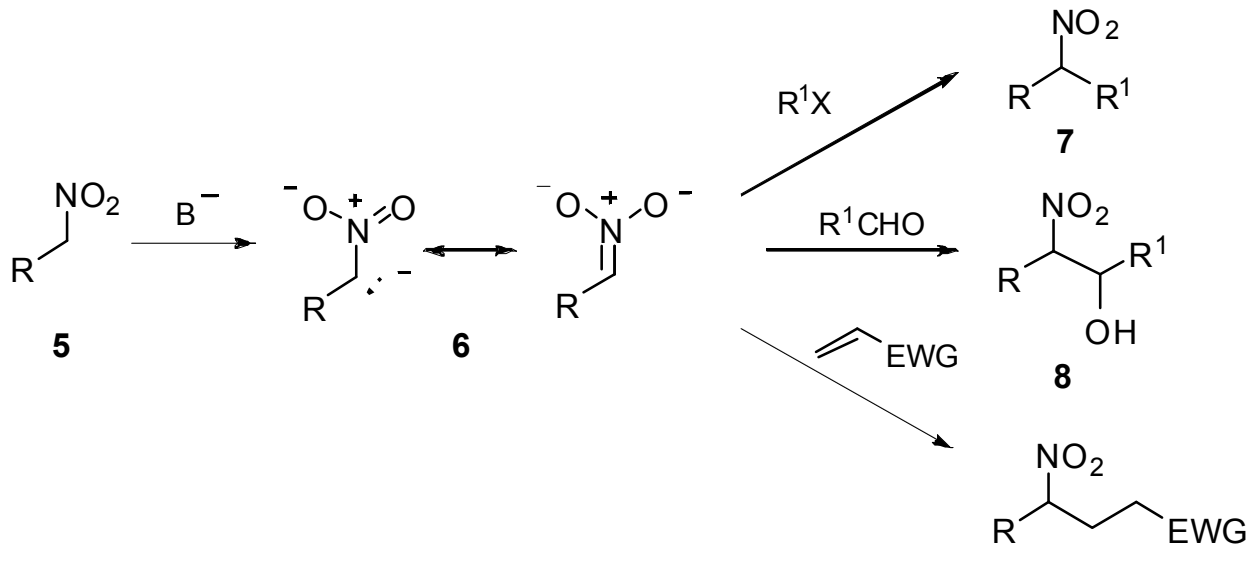

9

\section{Scheme 2}


Dehydration of the $\beta$-nitro-alcohols 8 obtained from nitro-aldol reactions affords nitroalkenes that act as efficient Michael acceptors and dienophiles in many reactions directed towards the formation of new carbon-carbon and carbon-heteroatom bonds. ${ }^{9-11}$ The aim of this review is to present a selected number of synthetic procedures dealing with the utilization of nitroalkanes as pivotal intermediates for the synthesis of heterocyclic derivatives. The discussion only includes those methods in which the nitro group is directly involved in the formation of the heterocycle.

\section{Lactones}

\section{$1.1 \gamma$ - Lactones}

A simple procedure for the preparation of $\gamma$-jasmolactone 13, a constituent of the essential oil of jasmine flowers, entails the utilization of the nitroheptene $\mathbf{1 0}$ that can be added to methyl acrylate in the presence of Amberlyst A21 as the basic promoter (Scheme 3). ${ }^{12}$ The nitro- ester 11 is then converted into the $\gamma$-keto ester 12 which upon chemoselective reduction with $\mathrm{NaBH}_{4}$ directly affords $\gamma$-jasmolactone $\mathbf{1 3}$ in satisfactory overall yield.

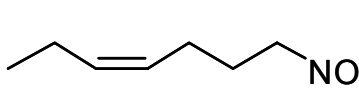

10

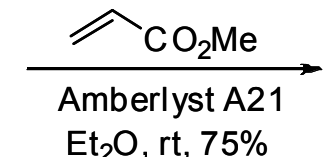

$\mathrm{Et}_{2} \mathrm{O}, \mathrm{rt}, 75 \%$

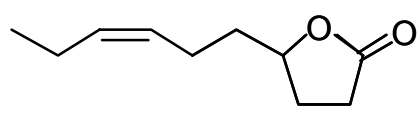

13

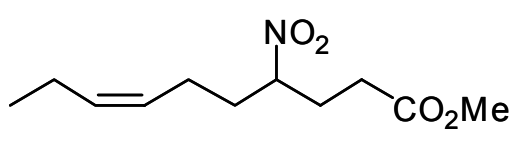

11
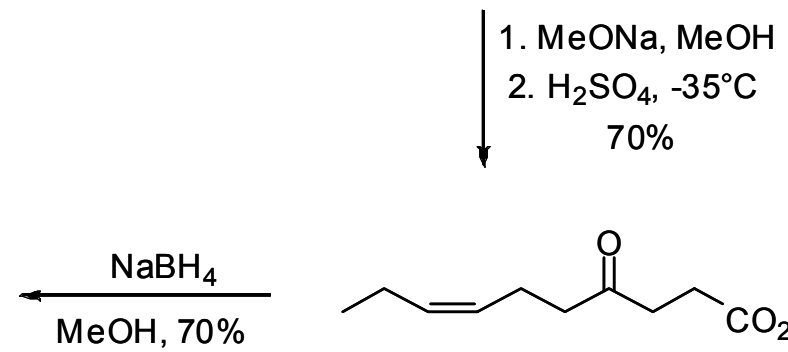

$\mathrm{MeOH}, 70 \%$

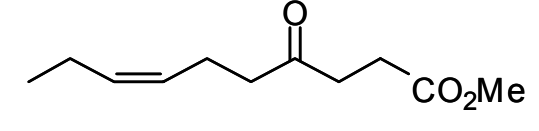

12

\section{Scheme 3}

The carbonyl group in the obtained $\gamma$ - keto esters can also be reduced enantioselectively, thus forming optically active $\gamma$-hydroxy- esters leading to chiral lactones. This approach is outlined for the stereoselective synthesis of $(R)$ - trans whisky lactone 18, the key flavor of some alcoholic beverages, and $(R)$ - eldanolide 19, the pheromone of the male African sugarcane stem borer (Scheme 4). ${ }^{13}$ Conjugate addition of nitroalkanes 14 to acrolein provides the corresponding derivatives 15 which by oxidation with hydrogen peroxide are converted into the keto acids $\mathbf{1 6}$. Enantioselective reduction of the carbonyl group using baker's yeast directly affords the lactones 17. Installation of a double bond into the lactones $\mathbf{1 7}$, and conjugate addition of dimethyllithium cuprate to the resulting butenolide completes the synthesis of compounds $\mathbf{1 8}$ and $\mathbf{1 9 .}$ 

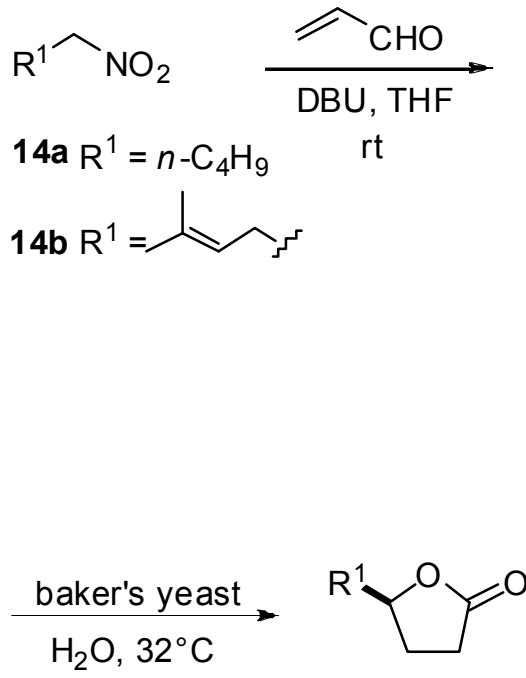

17a: $45 \%$

17b: $54 \%$<smiles>[R]C(CCC(=O)O)[N+](=O)[O-]</smiles>

$0^{\circ} \mathrm{C}$

15a: $81 \%$

15b: $79 \%$<smiles>[R]C(=O)CCC(=O)O</smiles>

16a: $76 \%$

16b: $73 \%$

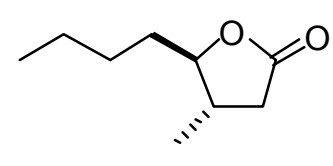

1. $n$-BuLi, $\mathrm{PhSeBr}$

2. $\mathrm{NaHCO}_{3}, \mathrm{NalO}_{4}$

3. $\mathrm{Me}_{2} \mathrm{CuLi}, \mathrm{THF},-78^{\circ} \mathrm{C}$
$(R)$-trans whisky lactone

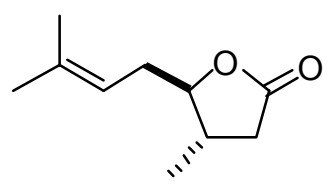

$19(70 \%)$

$(R)$-eldanolide

\section{Scheme 4}

$\gamma$ - Lactones bearing an exocyclic methylene group are of considerable interest because of their enhanced biological activity. Installation of this exo- unsaturation is not a trivial task, since regio-isomerization under a variety of conditions often leads to the more stable endocyclic derivative. Michael addition of primary nitroalkanes 14 with ethyl 2-bromoethyl acrylate 20 leads as usual to an intermediate enolate anion that upon elimination of the bromide anion gives the acrylates 21 (Scheme 5). ${ }^{14}$ The compounds 21 are then converted into keto esters, 22, by a classical Nef reaction and, after a chemoselective reduction of the carbonyl group under controlled conditions, are finally transformed into the lactones $\mathbf{2 3}$. 


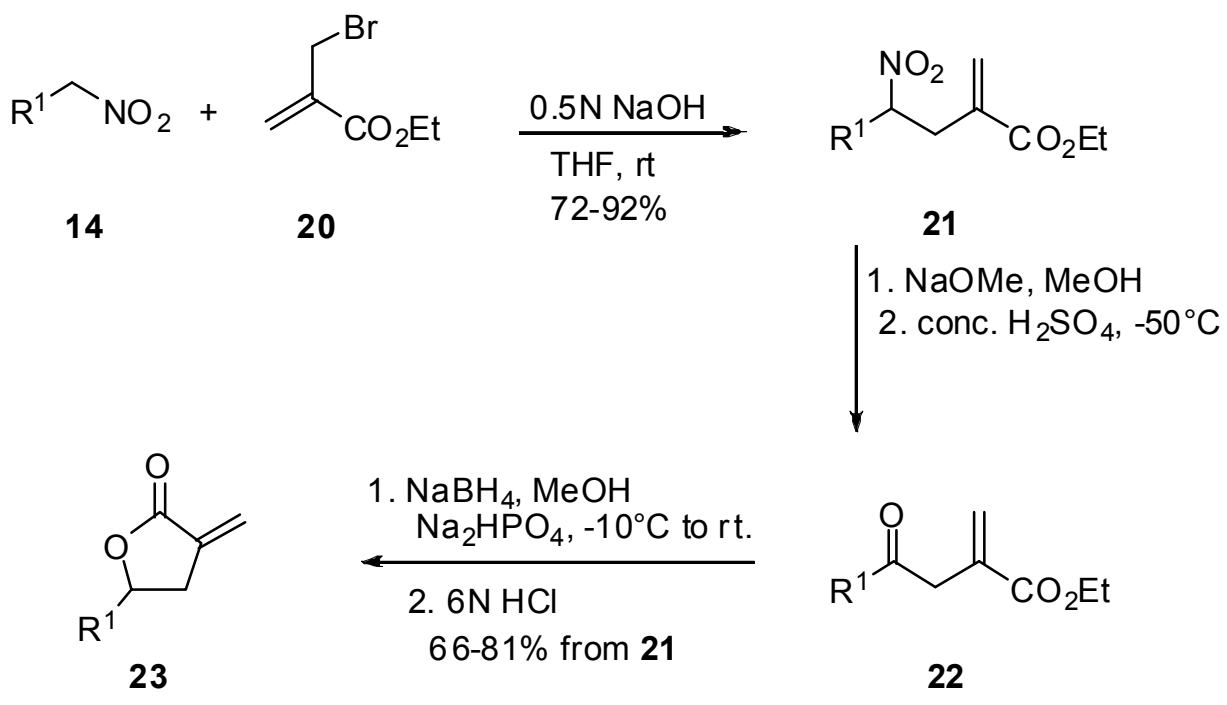

\section{Scheme 5}

\subsection{Macrolactones and dilactones}

Ring cleavage of cyclic 2-nitro-ketones by external nucleophiles provides rapid entry to $\omega$-nitroesters. ${ }^{15}$ 2-Nitrocycloalkanones $\mathbf{2 4}$ of different sizes are opened by methanol at reflux in the presence of Amberlyst A21, to give nitro-esters 25 (Scheme 6). ${ }^{16}$ The nitro group is converted into a hydroxy group by a sequential oxidative Nef reaction and reduction leading to hydroxy esters 26. These compounds can be cyclized to the corresponding macrolactones under different reaction conditions as demonstrated for the C-15 hydroxy ester $\mathbf{2 6}(n=11)$ which by Lipase $\mathrm{P}$ catalysis is converted into exaltolide $\mathbf{2 8}$, an important perfume isolated from angelica root oil.

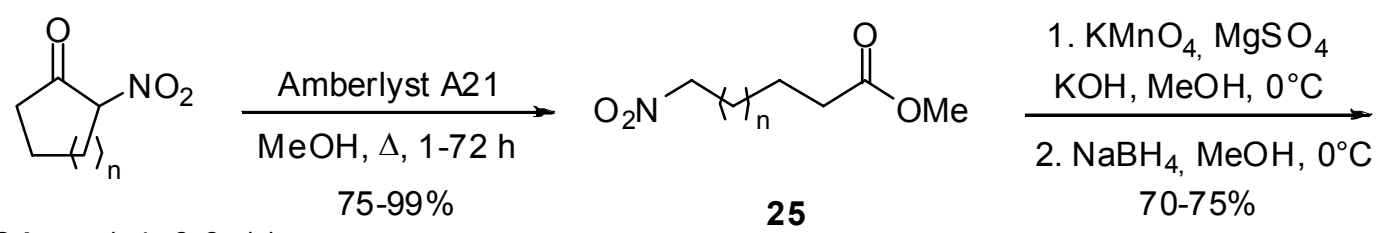

$24 n=1-4,6-8,11$

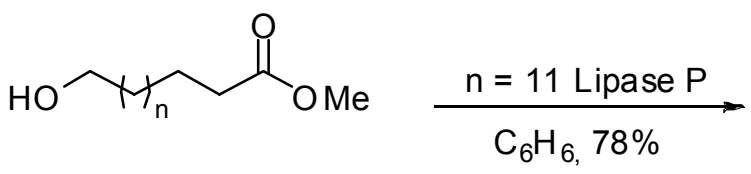

26

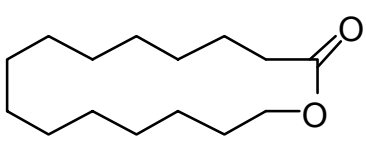

exaltolide 27

\section{Scheme 6}

An interesting outcome is observed in the ring cleavage of 2-nitro-cyclododecanone, 28, by potassium carbonate in a $30 \%$ solution of formaldehyde (Scheme 7 ).$^{17}$ The obtained 
macrolactone, 29, is the result of a, "zip reaction", 18 on the intermediate $\mathbf{3 0}$ generated by reaction of the cycloalkanone $\mathbf{2 8}$ with two molecules of formaldehyde, followed by further addition of formaldehyde onto compound $\mathbf{3 1}$.<smiles>O=C1CC[13CH]C1[N+](=O)[O-]</smiles>

28<smiles>COCCOCOCC1([N+](=O)[O-])CCCC1=O</smiles>

30

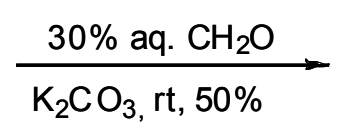

29<smiles>O=C(CCCCCCCCCCC(CO)(CO)[N+](=O)[O-])OCO</smiles>

zip reaction

31<smiles></smiles>

\section{Scheme 7}

Conjugate addition of the 2-nitro-cycloalkanones $\mathbf{3 2}$ to acrolein gives the corresponding aldehydes 33 which upon reduction with $\mathrm{NaBH}_{4}$ afford the alcohols 34 (Scheme 8). ${ }^{19}$<smiles>O=C1CCCCC1[N+](=O)[O-]</smiles><smiles>C/C=C\COCCOCCO</smiles>

$32 \mathrm{n}=1,2,3,7$<smiles>O=CCCC1([N+](=O)[O-])CCCCC1=O</smiles>

33<smiles>CC(C)[R10](=O)O</smiles>

$84-93 \%$

34

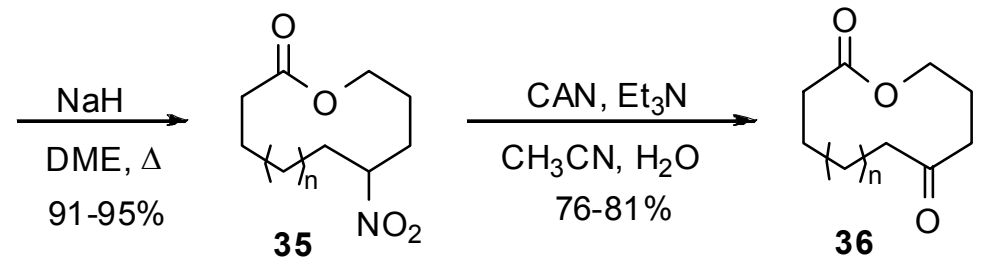

\section{Scheme 8}

An intramolecular retro-Claisen cleavage promoted by $\mathrm{NaH}$ allows the preparation of macrolactones 35 that are converted into keto- esters 36 by oxidative Nef reaction using cerium ammonium nitrate (CAN). The optically active nitro- acetate 37 can be readily prepared by 
enzymatic acylation from the corresponding racemic nitro- alcohol and reacts efficiently with methyl propiolate giving the corresponding adduct $(E)-\mathbf{3 8}$ (Scheme 9 ). ${ }^{20}$ The nitro group is then converted into the keto-ester 39 using the McMurry method, ${ }^{21}$ and after ester hydrolysis the resulting hydroxy acid is lactonized to the macrolide $(R)$ - patulolide $\mathrm{A}, \mathbf{4 0}$.<smiles>C#CC(=O)OCC(C)OC(C)CCCCCCC(C=CC(OC)OC(C)=O)C(C)OC(C)=O</smiles>

37

38

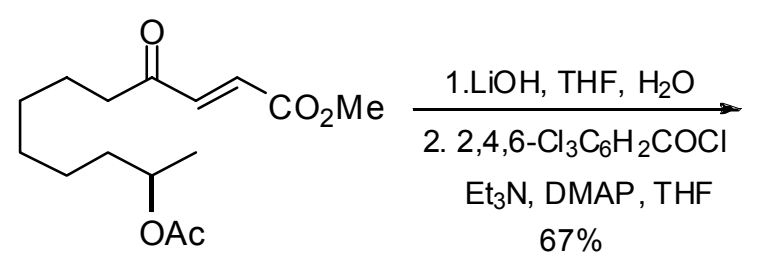

39<smiles>C[C@@H]1CCCCCCC(=O)/C=C/C(=O)O1</smiles>

(R)-patu lolide A 40

\section{Scheme 9}

A related strategy is also effective for the total synthesis of optically active $(R, R)-(-)$ pyrenophorin, 42, an antifungal macrolide dilactone, starting from the nitro- ester 41 (Scheme $10)^{22}$

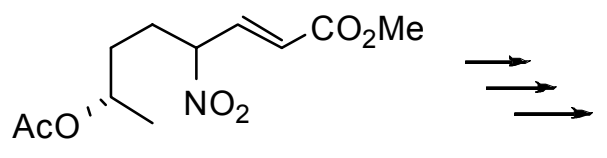

41<smiles>C[C@H]1CCC(=O)/C=C/C(=O)[C@@H](C)CCC(=O)/C=C/C(=O)O1</smiles>

(-)-pyre nophorin 42

\section{Scheme 10}

\section{Spiroketals}

The spiroketal system is present in a considerable number of natural products obtained from plants, fungi, insect secretions, shellfish toxins, and other living organisms. ${ }^{23}$ Many of these bicyclic compounds also show high biological activity as antibiotics and pheromones. Among various practical strategies currently available for assembling the spiroketal unit, the acid- 
promoted intramolecular acetalization of dihydroxy-ketone derivatives firmly occupies a central position. Conjugate addition of nitroalkanes to enones provides a rapid entry to 1,4difunctionalized derivatives. Particularly, nitromethane can be regarded as a multiple coupling reagent corresponding to a carbonyl dianion synthon. A double Michael addition of nitromethane 43 using two different $\alpha, \beta$-unsaturated carbonyl derivatives can be used as a key strategy for the preparation of racemic 2-ethyl-1,6-dioxaspiro[4.4]nonane, 47, known as "Chalcogran", which is the main component in the aggregation pheromone of the bark beetle Pityogenes chalcografus (L) (Scheme 11). ${ }^{24}$ Addition of nitromethane $\mathbf{4 3}$ to 1-penten-3-one in the presence of basic alumina under solvent-free conditions affords the corresponding 4-nitro- ketone $\mathbf{4 4}$ that is suitable for a subsequent conjugate addition to acrolein under the same conditions, leading to the nitro- diketone 45. Reduction of the carbonyl groups with $\mathrm{NaBH}_{4}$ generates the nitro- diol $\mathbf{4 6}$, which upon nitro- to carbonyl- conversion spontaneously produces the spiroketal system of chalcogran $\mathbf{4 7}$ as a mixture of stereoisomers in $20 \%$ overall yield.
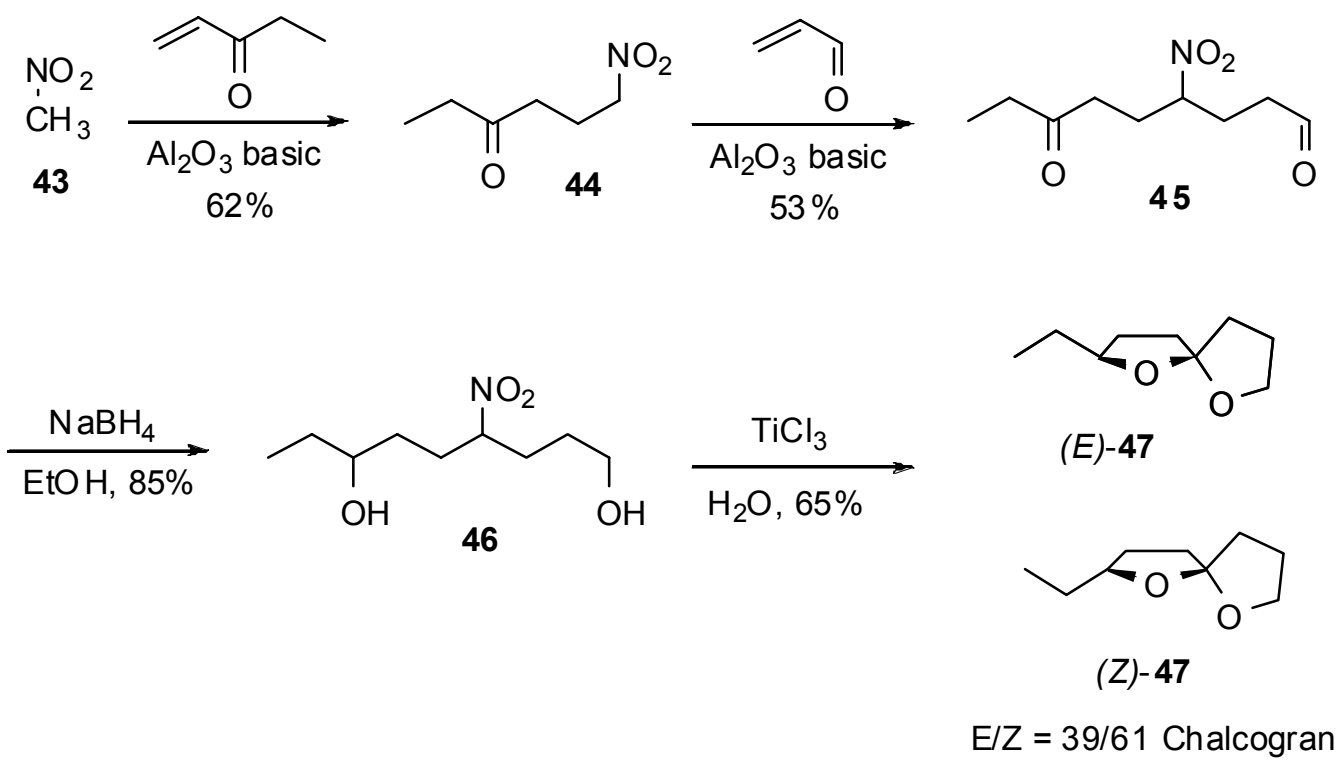

\section{Scheme 11}

As shown previously for the synthesis of lactones, 2-nitro-cycloalkanones react with various enones, leading to adducts 48 (Scheme 12) ${ }^{25}$ The following three synthetic operations, retroClaisen cleavage, reduction, and nitronate formation, can be carried out on the adducts $\mathbf{4 8}$ in a single step using $\mathrm{NaBH}_{4}$ in a mixture of acetonitrile-water (3:2). The intermediate nitronate 49 upon quick acidic hydrolysis affords directly the spiroketals 50. In conclusion, this versatile strategy also allows for a rapid entry to 1,6-dioxaspiro[4.6]undecane systems.

The nitro-aldol (Henry) reaction between the nitro-alcohol $\mathbf{5 1}$ and O- protected hydroxyaldehydes, 52, occurs efficiently under heterogeneous conditions, leading directly to nitroalkenes 53 (Scheme 13). ${ }^{26}$ As usual, reduction of the nitroalkene double bond is also coupled with formation of the nitronate anion $\mathbf{5 4}$ that upon acidification undergoes a THP deprotection, Nef 
reaction, and ketalization, affording the spiroketals 55. These compounds are the main components of the sex pheromones of the olive fruit fly (Dacus oleae) (55a) and Andrena haemorrhoa (55b). Following a related strategy in which a 5-nitro-ketone and a 4-hydroxyaldehyde are used for the nitro-aldol reaction, other dialkyl-1,7-dioxaspiro[5.5]undecanes can be readily obtained. ${ }^{27}$<smiles>[R]C(=O)C=CC(=O)O[Na]</smiles><smiles>[R]C(=O)CCC1([18O])[13CH]CCC1=O</smiles>

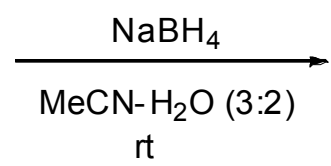<smiles>[R]C(O)CCC(CCCO)=[N+]([O-])OC</smiles>

$2 \mathrm{~N} \mathrm{HCl}$

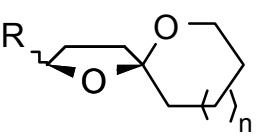

50

\begin{tabular}{c|cccc} 
& $\mathrm{n}$ & $\mathrm{R}$ & yield (\%) & $\mathrm{E}: \mathrm{Z}$ \\
\hline a & 1 & $\mathrm{Me}$ & 65 & $3: 2$ \\
b & 1 & $\mathrm{Et}$ & 70 & $3: 2$ \\
c & 2 & $\mathrm{Me}$ & 75 & $3: 2$ \\
d & 2 & $\mathrm{H}$ & 60 & -
\end{tabular}

\section{Scheme 12}


<smiles>[R]C(O)CCCC[Hg]</smiles>

52

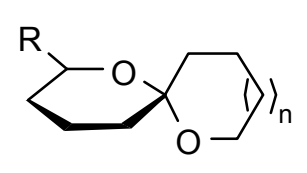

55<smiles>[R]C(O)CCCC(=CCCC(=O)[O-])[N+](=O)[O-]</smiles>

53

$\mathrm{NaBH}_{4}$

$\mathrm{MeOH}$

$\underline{2 \mathrm{~N} \mathrm{HCl}}$

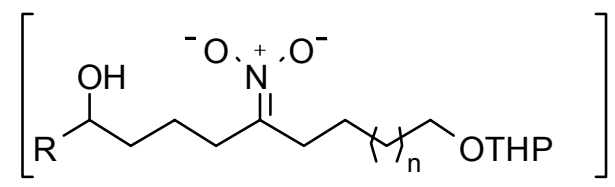

54

\begin{tabular}{|c|c|c|c|c|c|}
\hline & $\mathrm{n}$ & $\mathrm{R}$ & 53 & yield (\%) & 55 \\
\hline a & 1 & $\mathrm{H}$ & 53 & & 64 \\
\hline b & 2 & $\mathrm{Me}$ & 54 & & 66 \\
\hline
\end{tabular}

\section{Scheme 13}

\section{Pyrrolidines and derivatives}

\subsection{Pyrrolidin-2-ones}

Reduction of the nitrogen atom, thus generating amino derivatives, represents the most obvious transformation of the nitro group. When an ester function is also present in the substrate at the $\gamma$ position, a chemoselective reduction of the nitro group directly affords pyrrolidin-2-one derivatives. Addition of nitroalkanes 5 to Baylis-Hillman products 56 gives the corresponding unsaturated nitro- esters 57 that are chemoselectively reduced by a 'one pot' procedure to the corresponding 2-alkylidenepyrrolidinones 58 using Fe in boiling $\mathrm{AcOH}$ (Scheme 14). ${ }^{28}$ 
<smiles>[R]C(OC(C)=O)C(=C)C(=O)OC</smiles>

56

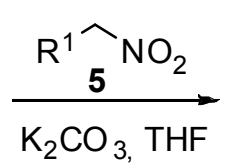

$\mathrm{K}_{2} \mathrm{CO}_{3}, \mathrm{THF}$

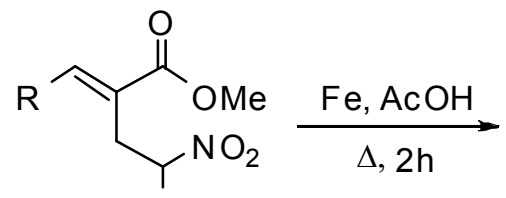

$57 \mathrm{R}^{1}$<smiles>[R]C=C1CC([R])NC1=O</smiles>

58

\begin{tabular}{|lll|}
\hline $\mathrm{R}^{1}$ & $\mathrm{R}$ & $\mathbf{5 8}$ yield (\%) \\
\hline $\mathrm{Me}$ & $\mathrm{Ph}$ & 66 \\
$\mathrm{Me}$ & $4-\mathrm{Cl}-\mathrm{C}_{6} \mathrm{H}_{4}$ & 64 \\
$\mathrm{Et}$ & $4-{\mathrm{Me}-\mathrm{C}_{6} \mathrm{H}_{4}} 62$ \\
$\mathrm{Et}$ & $2-\mathrm{Cl}-\mathrm{C}_{6} \mathrm{H}_{4}$ & 60 \\
\hline
\end{tabular}

\section{Scheme 14}

The introduction of a methylene group at a 2- position is more achievable using 2diethoxyphosphoryl acrylate 59 that reacts with nitroalkanes 5 and $\mathrm{NaH}$, giving the adduct 60 (Scheme 15). ${ }^{29}$ Reduction of the nitro group occurs with concomitant lactamization, leading to pyrrolidin-2-ones, 61. Reaction of $\mathbf{6 1}$ with formaldehyde provides a 2-methylenepyrrolidin-2one, 62, along with variable amounts of the corresponding 1-hydroxymethyl derivative, 63.<smiles>[R]C1CC([PH](=O)OCC)C(=O)N1</smiles>

61

R

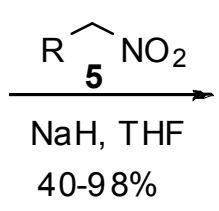

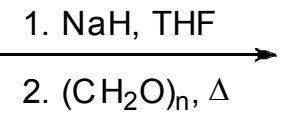<smiles>[R]C(CC(C(=O)OC)P(=O)(O)OCC)[N+](=O)[O-]</smiles>

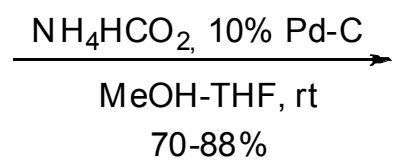<smiles>[R]C1CC(=C)C(=O)N1</smiles>

$62(40-76 \%)$<smiles>[R]C1CC(=C)C(=O)N1CO</smiles>

$63(6-26 \%)$

\section{Scheme 15}

Nitromethane addition to the diester 64 affords the product 65 which upon reduction of the nitro group and ester hydrolysis gives the pyrrolidinone 66 (Scheme 16). ${ }^{30}$ The acid 66 can be transformed easily in a few steps into the bicyclo- $\gamma$-lactam 67 that acts as an inhibitor of penicillin- binding proteins. Dissymmetric hydrolysis of racemic 66 using two enantiocomplementary enzymes allows the preparation of optically active $\mathbf{6 6}$ in both enantiomeric forms. ${ }^{31}$ 


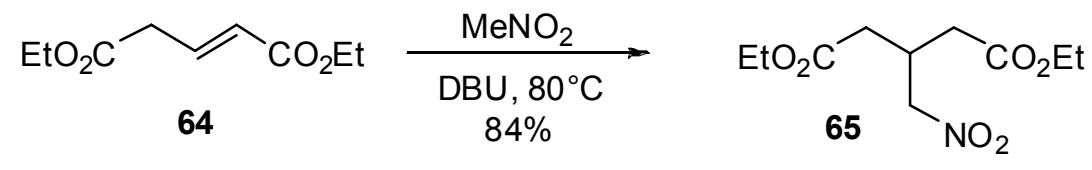

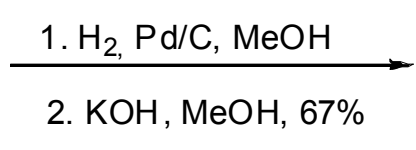

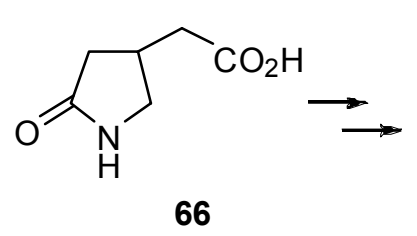

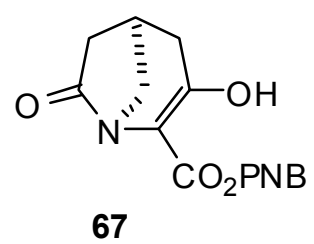

\section{Scheme 16}

Methyl 2-bromoacrylate 69 can be generated in situ from the corresponding dibromo derivative 68 and then made to react with the nitro- compound 70 to give adduct 71 (Scheme 17). ${ }^{32}$ Substitution of the halogen with an hydroxy group is followed by reduction of the nitro group by catalytic hydrogenation to give the pyrrolidinone 73 . This derivative can be converted into aza-iso- nucleotide analogs by further simple synthetic manipulations. 3,4-Dihydroxy pyrrolidinones structurally related to compound $\mathbf{7 3}$ can be obtained using the same strategy, by conjugate addition of the nitroalkane $\mathbf{7 0}$ to ethyl propynoate, formed in situ, followed by dihydroxylation of the resulting unsaturated derivative. ${ }^{33}$

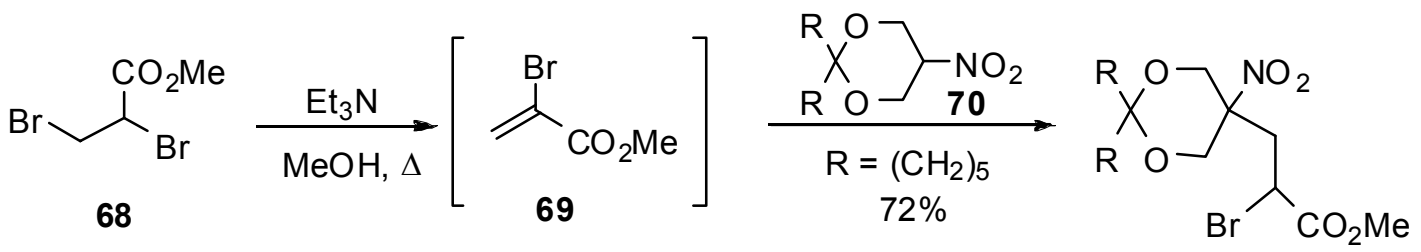

71

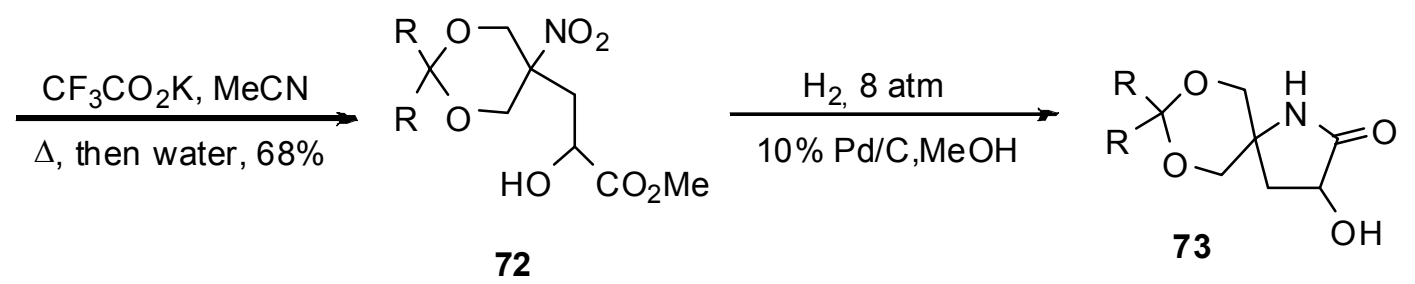

\section{Scheme 17}

Diastereoselective conjugate addition of nitroalkanes to the chiral (Z)- enoate $\mathbf{7 4}$ leads to the synthesis of compounds $\mathbf{7 5}$ with predominance of the syn stereoisomer (Scheme 18). ${ }^{34}$ Interestingly, the $E$ isomer of compound $\mathbf{7 4}$ fails to provide good diastereoselection in the same process. ${ }^{35}$ The stereoselectivity at the carbon atom bearing the nitro group in compound $\mathbf{7 5 b}$ is rather poor, and this result is probably due to the high acidity of the hydrogen atom between the 
nitro and ester groups. Reduction of the nitro group and ring closure affords pyrrolidinones $\mathbf{7 6}$ that can be used as synthetic intermediates in the preparation of several interesting compounds.
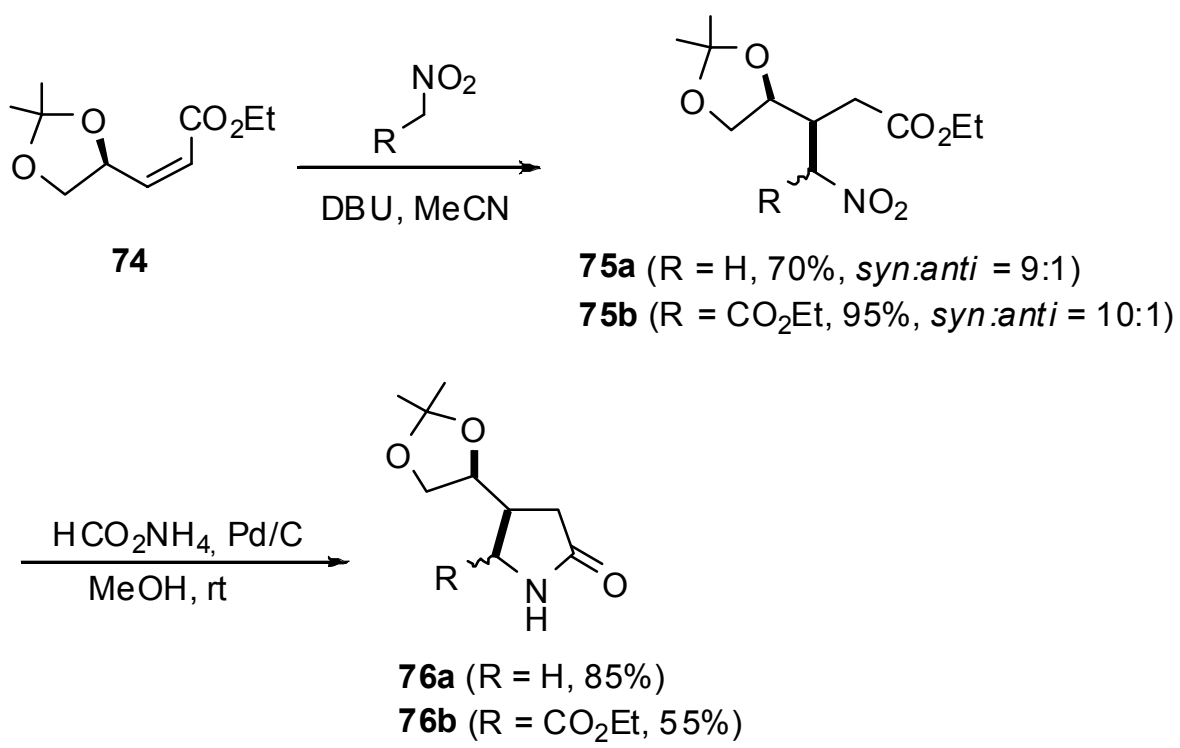

\section{Scheme 18}

The functionalized nitrocyclopentane $\mathbf{7 7}$ reacts with methyl acrylate in quantitative yield to give adduct $\mathbf{7 8}$ as a single diastereomer, probably because of the stereo-directing effect of the vicinal phenyl group (Scheme 19). ${ }^{36}$ Reduction of the nitro group using zinc metal in ethanolic $\mathrm{HCl}$ affords spirolactam $\mathbf{7 9}$ without any migration of the exocyclic double bond. The lactam $\mathbf{7 9}$ is a key intermediate for the synthesis of the alkaloid cephalotaxine.

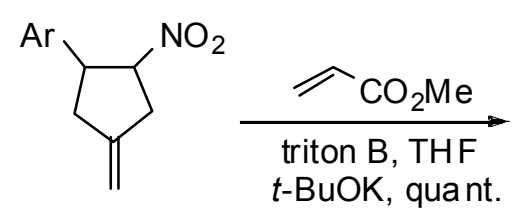

77

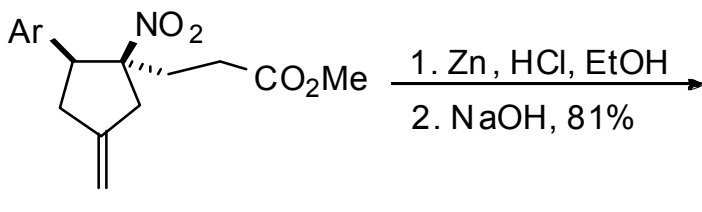

78

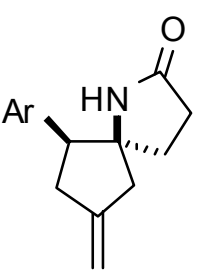

79

\section{Scheme 19}

Conjugate addition of nitromethane to enals can be carried out under catalytic conditions using chiral pyrrolidines derived from $(S)$ - proline in aqueous solutions. The water-compatible iminium catalysis occurs with outstanding enantioselectivity and can be used for the synthesis of the type IV phosphodiesterase inhibitor (S)- Rolipram (Scheme 20). ${ }^{37}$ The unsaturated aldehyde $\mathbf{8 0}$ reacts with nitromethane in the presence of a pyrrolidine catalyst giving the adduct $\mathbf{8 1}$ which is further oxidized and converted into the corresponding methyl ester $\mathbf{8 2}$ in satisfactory yield and 
high enantioselectivity. Reduction of the nitro group and spontaneous lactamization complete the synthesis of $(S)$ - Rolipram $\mathbf{8 3}$.
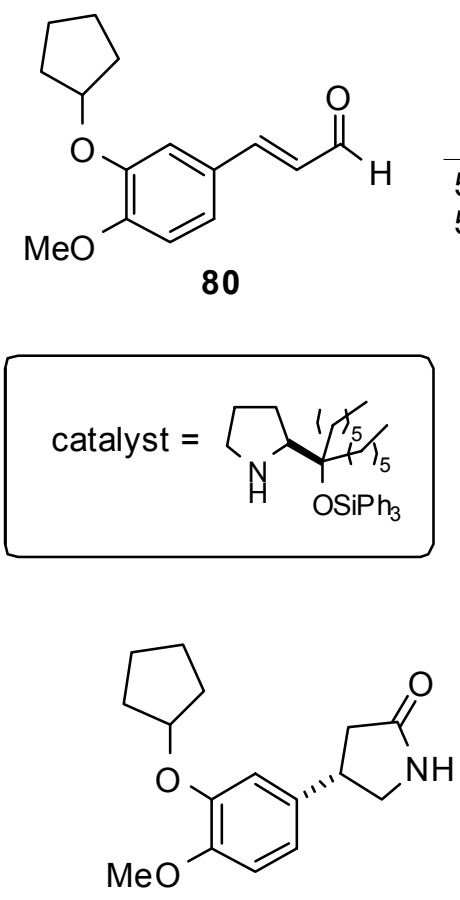

(S)-Rolipram 83

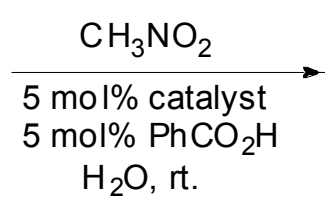

$\mathrm{H}_{2} \mathrm{O}$, rt.<smiles>COc1ccc(C(CO)CC(=O)[O-])cc1OC1CCCC1</smiles>

81

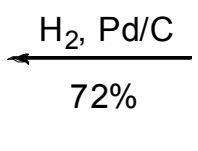

$8262 \%$, ee $=98 \%$

\section{Scheme 20}

\subsection{Pyrrolidines and related bicyclic derivatives}

Pyrrolidines can be obtained easily by reduction of the corresponding pyrrolidin-2-ones prepared as discussed in the previous Section. Alternatively, the primary amine obtained by reduction of the nitro group may react with other functional groups (such as carbonyls, giving imino derivatives) that upon further reduction lead to the formation of the pyrrolidine ring. The unsaturated nitrile $\mathbf{8 4}$ reacts with nitromethane giving the corresponding adduct $\mathbf{8 5}$, which upon catalytic hydrogenation with $10 \% \mathrm{Pd} / \mathrm{C}$ in $\mathrm{MeOH} / \mathrm{AcOH}(9: 1)$ and acylation furnishes $N$ trifluoroacetylpyrrolidine 86 (Scheme 21). ${ }^{38}$ It is probable that the primary amine formed by reduction of the nitro group reacts with the intermediate imine formed by reduction of the nitrile to give the intermediate pyrrolidine. Compound $\mathbf{8 6}$ is an intermediate for the preparation of synthetic analogues of Sinefungin, a nucleoside active against viruses, fungi and parasites. 


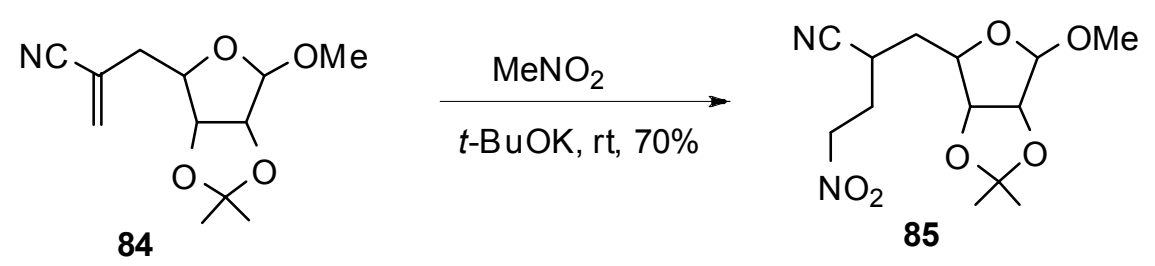

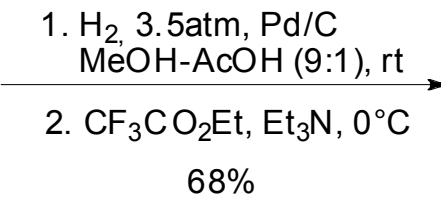

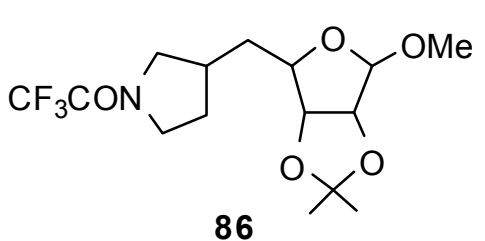

86

\section{Scheme 21}

Conjugate addition of the nitrolactam $\mathbf{8 7}$ with acrylophenone $\mathbf{8 8}$ gives compound $\mathbf{8 9}$ with high diastereoselectivity (Scheme 22). ${ }^{39}$ Catalytic hydrogenation of the nitro-ketone 89 occurs with concomitant formation of an intermediate imine $\mathbf{9 0}$ that is reduced in the same conditions to the spiro-pyrrolidine 91. The presence of the phenyl group in the lactam ring hinders one face of the pyrroline ring in 90, thus allowing a complete diastereoselection in the imine reduction.

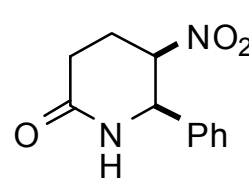

87

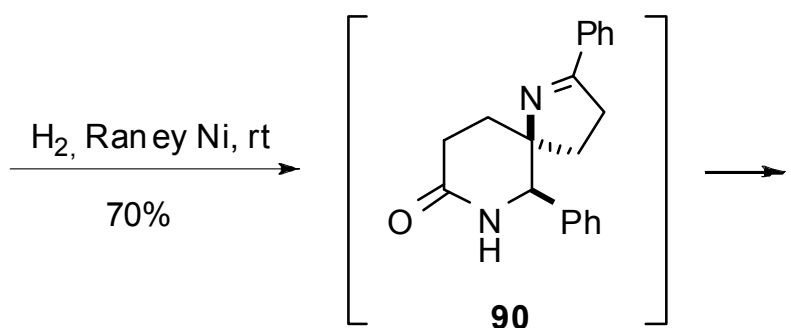<smiles>O=C1CCC(CCC(=O)c2ccccc2)([N+](=O)[O-])[C@H](c2ccccc2)N1</smiles>

89

\section{Scheme 22}

The Henry reaction between the chiral aldehyde 92 and the nitro- derivative 93 gives a mixture of three diastereomers in which compound 94 predominates (Scheme 23). ${ }^{40}$ Reduction by catalytic hydrogenation of the nitro-aldol 94 occurs with retention of the original configuration at the nitro group and at the same time provides debenzylation of the protected alcohol. Ring closure of the amino-polyol 95 is realized using the Appel reagent ${ }^{41}$ that selectively converts the primary hydroxyl into a good nucleofuge. After hydrolysis of the 
acetonide group, the hydrochloride salt of polyhydroxylated pyrrolidine 96 is obtained. Derivatives of type $\mathbf{9 6}$ are known as strong and selective glycosidase inhibitors.

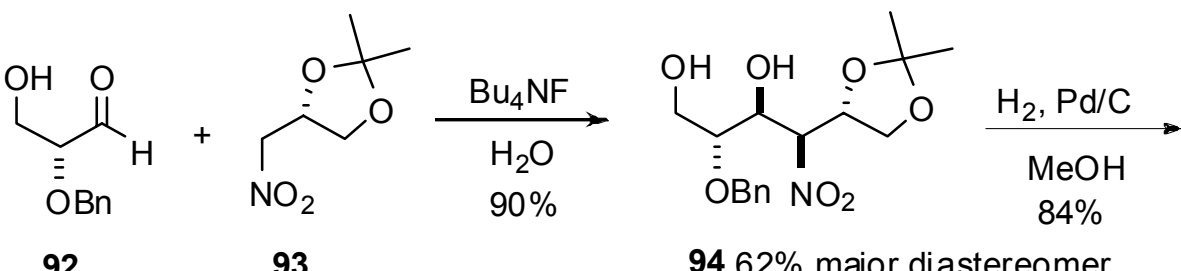

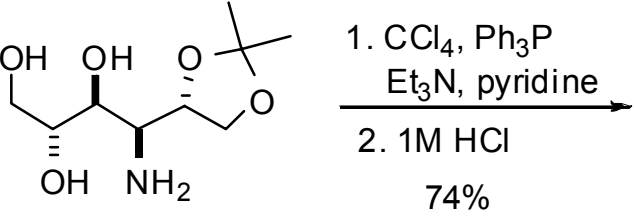

95<smiles>OCC(O)[C@H]1NCC(O)C1O</smiles>

96

\section{Scheme 23}

Hydroxylamines are known intermediates in the reduction of nitro- compounds to amines. The adducts 98 obtained by reaction of nitroalkanes, $\mathbf{1}$, and enones or enals, $\mathbf{9 7}$, can be reduced using various metals in acidic conditions (Scheme 24). ${ }^{42-44}$ The intermediate hydroxylamines 99 produce directly the cyclic nitrones $\mathbf{1 0 0}$ by an intramolecular reaction with the carbonyl group.

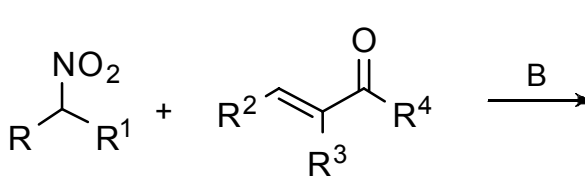

1

97<smiles>[R]C(=O)C([R])C([R])C([R])([R])[N+](=O)[O-]</smiles>

98<smiles>[R]C(NO)C([R])C([R3])C([R])C([R])([R])NO</smiles>

\section{Scheme 24}

The presence of two carbonyl groups in nitro- diketones, allows the synthesis of pyrrolizidines and indolizidines, which are alkaloid derivatives and can have useful biological activity. The nitro- diketone $\mathbf{1 0 3}$ is readily obtained by addition of nitro-ketone $\mathbf{1 0 1}$ to the vinyl 
ketone $\mathbf{1 0 2}$ in the presence of $\mathrm{Bu}_{3} \mathrm{P}$ (Scheme 25). ${ }^{45}$ Reduction of compound $\mathbf{1 0 3}$ produces a mixture of stereoisomeric pyrrolizidines 104 and 105 whose diastereomeric composition depends on the reducing system used. Catalytic hydrogenation (method A) favors the formation of compound 104, while the utilization of complex hydrides (method B) favors the isomer 105, an alkaloid known as Xenovenine.

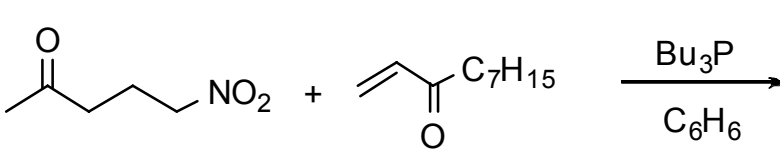

101
102<smiles>CCCCCCCC(=O)CCC(CCC(C)=O)[N+](=O)[O-]</smiles>

103 method $A: \mathrm{H}_{2}(8-10 \mathrm{~atm}), \mathrm{Pd} / \mathrm{C}, \mathrm{EtOH}$ 104:105 $=65: 5$

method B: $\mathrm{NH}_{4} \mathrm{OAc}, \mathrm{KOH}, \mathrm{MeOH}$ $\mathrm{NaBH}_{3} \mathrm{CN}$, then $\mathrm{NaBH}_{4}$, 104:105 = 12:88

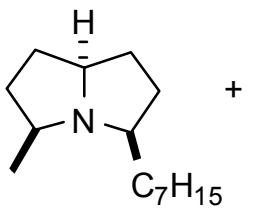

104

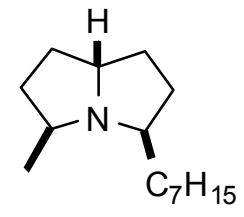

xenovenine 105

\section{Scheme 25}

2-Nitro-ketones usually undergo conjugate additions under milder conditions than do nitroalkanes because of the enhanced acidity of the C-2 hydrogen atom. 2-Nitrocyclohexanone, 106, reacts with unsaturated ketone 107 in the presence of $\mathrm{Ph}_{3} \mathrm{P}$ to give the corresponding adduct 108 (Scheme 26). ${ }^{46}$ The cyclohexanone moiety in 108 suffers a fast base-catalyzed retro- Claisen ring opening, affording the open- chain nitro derivative 109 which under reductive conditions chemoselectively furnishes the cis-pyrrolidine 110. This compound is a central intermediate for the synthesis of the indolizidine alkaloid monomorine I, 111, a trail pheromone of the Pharaoh Ant, and other similar biologically active substances. ${ }^{47}$ 


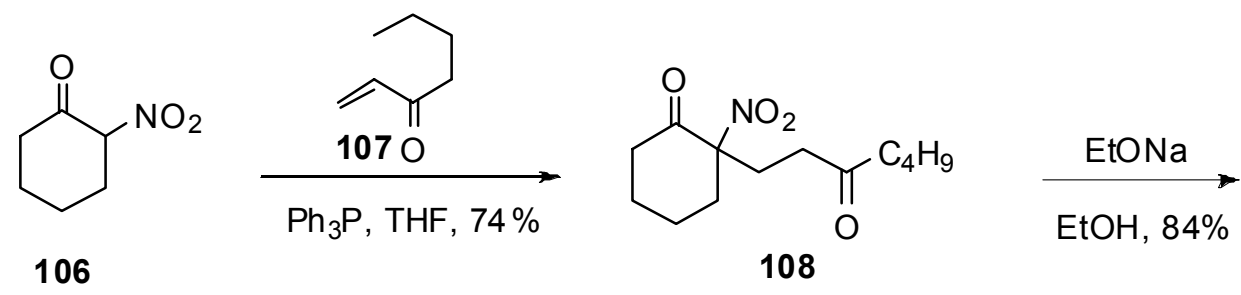<smiles>CCOCCCCC(CCC(C)=O)[N+](=O)[O-]</smiles>

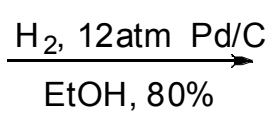<smiles>CC1CCC[C@@H]2CCC(C)C12</smiles>

monomorine | 111

\section{Scheme 26}

$\alpha$-Amidoalkyl sulfones are stable precursors of $N$-acylimino derivatives and can be used in the reaction with various nucleophilic reagents. ${ }^{48}$ The chiral $\alpha$-amido- sulfone 113 can be readily obtained by reaction of $(S)$-prolinal 112 with $\mathrm{BocNH}_{2}$ and benzenesulfinic acid (Scheme 27). ${ }^{49}$ Reaction of the $\alpha$-amido- sulfone 113 under basic conditions initially produces the $N$-acylimine 114 that subsequently adds the nitromethane anion leading to the corresponding adduct, 115, with satisfactory diastereoselectivity. Oxidation of the carbon bearing the nitro group and further alkylation gives the methyl ester 116 that is transformed into the chiral piperazine 117, an $\alpha$ amino acid derivative that finds several practical applications as a chiral catalyst as well as a building block for the synthesis of HIV-protease inhibitors. 

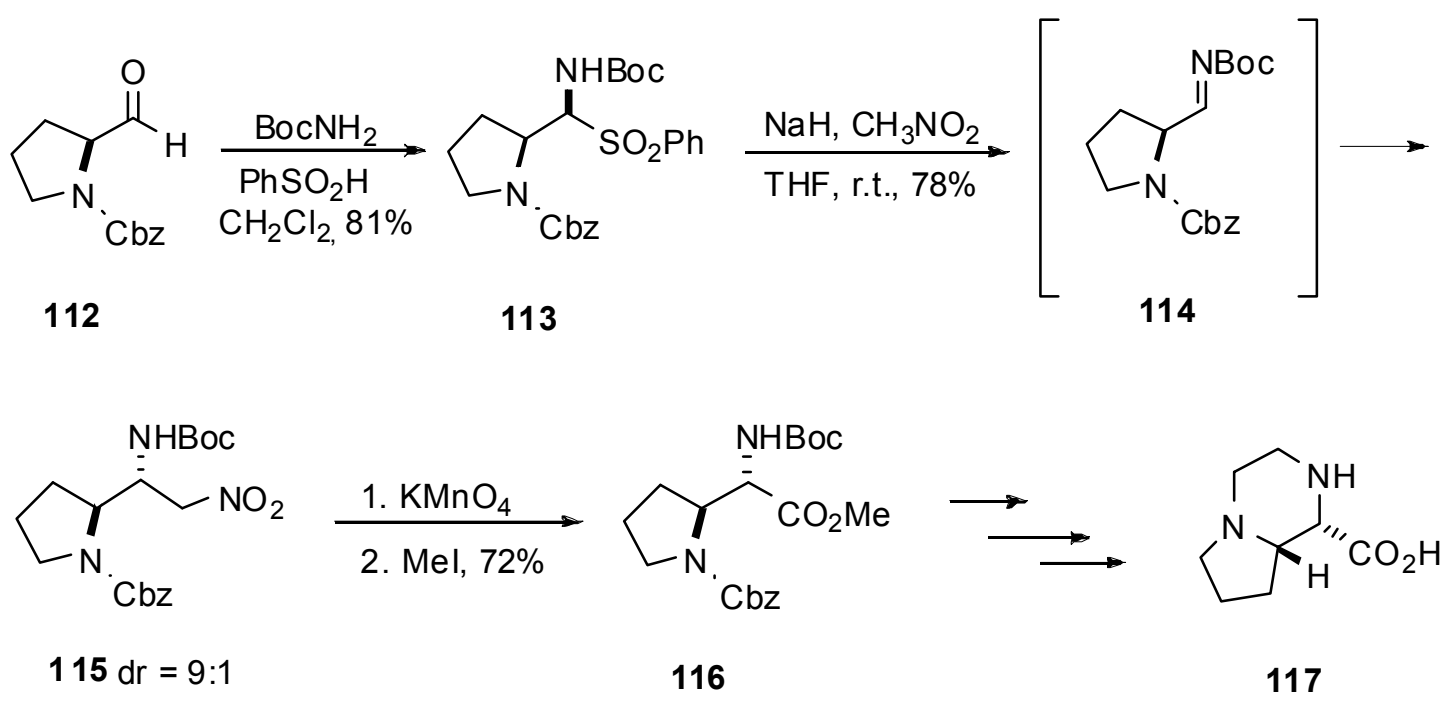

Scheme 27

\section{Piperidines and Related Derivatives}

The synthesis of piperidine derivatives 118, 119 by reduction of a nitro group and subsequent cyclization would entail a preliminary formation of 1,5-difunctionalized systems $\mathbf{1 2 0}$ which are not directly achievable by conjugate additions or similar processes (Scheme 28).<smiles>[R]C1CCCCN1</smiles>

118<smiles>[R]C1CCCC(=O)N1</smiles>

119<smiles>[R]OC(=O)CCCC([R])[N+](=O)[O-]</smiles>

120

\section{Scheme 28}

Various functional groups can be introduced into $\omega$-nitro-1-alkenes by exploiting a crossmetathesis reaction with functionalized alkenes in the presence of Grubbs II catalyst, as illustrated for the synthesis of the nitro- ester 122 from 6-nitrohex-1-ene, 121, and $t$ - butyl acrylate (Scheme 29). ${ }^{50}$ Chemoselective reduction of the nitro group with sulfurated sodium borohydride reagent gives the corresponding amine which, by intramolecular conjugate addition with the unsaturated ester portion, leads to the $\alpha$-substituted piperidine $\mathbf{1 2 3}$. 


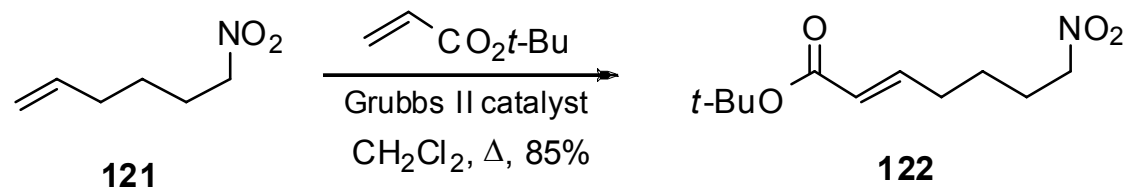

$\underset{\mathrm{THF}, \Delta, 82 \%}{\stackrel{\mathrm{NaBH}_{2} \mathrm{~S}_{3}}{\longrightarrow}}$<smiles>CC(C)OC(=O)CC1CCCCN1</smiles>

123

\section{Scheme 29}

An interesting procedure to install the nitro and ester groups in a proper 1,5- position consists in the reaction of the functionalized copper-zinc reagent 124 to $(E)$-2-nitro-1-propenyl phenyl sulfide (Scheme 30). ${ }^{51,52}$ The addition-elimination reaction occurs with high $E$ - stereoselectivity, allowing the formation of the nitroalkene $\mathbf{1 2 5}$ which is then reacted with Danishefsky's diene, leading to the nitro- cyclohexanone 126. After protection of the carbonyl group compound 127 undergoes a partial reduction to the hydroxylamine using $\mathrm{Al} / \mathrm{Hg}$ amalgam. The partial nature of the reduction is probably caused by the steric hindrance of the nitro group, and can be completed to the amino derivative using $\mathrm{TiCl}_{3}$. The piperidone derivative 128, which is isolated after spontaneous lactamization can be further reduced to the piperidine ring using Red-Al ${ }^{\circledR}$ under normal conditions. 
<smiles>CCOC(=O)CCC[AlH]NC=[Te]</smiles>

124<smiles>CCOCCC[C@H]1CC(=O)CC(OC)[C@@]1(C)[N+](=O)[O-]</smiles>

126<smiles>COC1CC2(CC3CCC(=O)NC32C)OCCO1</smiles>

128

$$
\underset{75 \%}{\stackrel{\mathrm{Red}_{\mathrm{Al}}{ }^{\circledR}}{\longrightarrow}}
$$
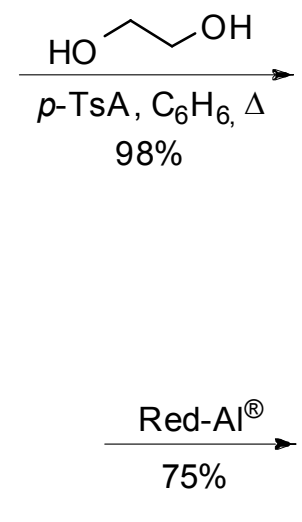<smiles>COC1CC2(CC3CCCNC31C)OCCO2</smiles>

129

\section{Scheme 30}

Highly functionalized chiral tetrahydro-isoquinolines can be prepared using a PictetSpengler reaction on suitable imino derivatives. The generation of a stereo- defined chiral center can be realized by a catalytic enantioselective nitro- aldol reaction of nitromethane on arylaldehydes such as $\mathbf{1 3 0}$ in the presence of copper- $\mathrm{C}_{2}$-symmetrical oligo-thiophene catalyst (Scheme 31). ${ }^{53}$ The resulting nitro-alcohol $\mathbf{1 3 1}$ is converted into the corresponding amino alcohol and then protected as the fluorenylmethoxycarbamate 132. This operation is required to carry out silylation of the hydroxy group, since the amine protection is subsequently removed, leading to primary amine 133. Conversion of amine 133 into the benzylidene imine 134 is followed by a metallo-free ring closure allowing the preparation of the final target in satisfactory diastereo- and enantioselectivities. 
<smiles>COc1cc(C=O)cc(OC)c1</smiles>

130

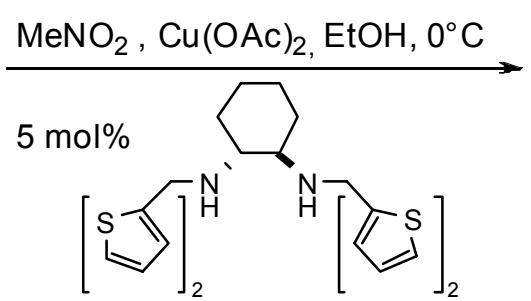<smiles>COc1cc(OC)cc([C@H](O)C[N+](=O)[O-])c1</smiles>

$13183 \%$, ee $=84 \%$

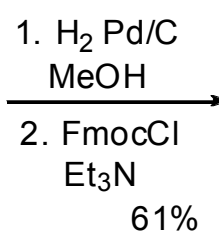

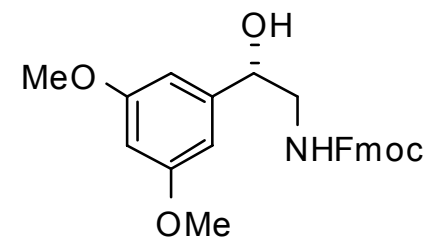

132

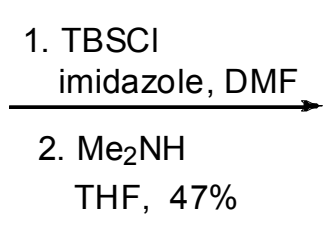

THF, $47 \%$<smiles>COc1cc(OC)cc([C@@H](CN)[OH+][SH3+])c1</smiles>

133

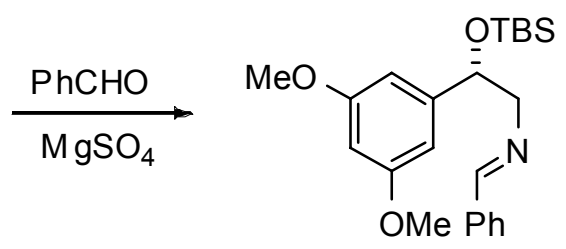

134

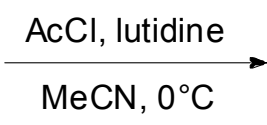

$13563 \%, d r=84: 16$, ee $=84 \%$

\section{Scheme 31}

\section{Polyheterocyclic Derivatives}

Nitroalkanes can be transformed into silyl nitronates by trapping the nitronate anion with trialkylsilyl halides. Silyl nitronates are useful 1,3- dipoles in cycloaddition reactions with alkenes leading to 2-isoxazolines which can be transformed subsequently into other heterocyclic derivatives. ${ }^{54} \mathrm{~A}$ new entry to the 2-isoxazoline nucleus makes use of the conjugate addition of ethyl nitroacetate, 137, with the 2-bromo-ketones, 136 (Scheme 32 ) ${ }^{55}$ The intermediate adduct 138 undergoes an intramolecular nucleophilic substitution involving the oxygen of the nitronate anion and the bromine atom. The reaction can be realized in homogeneous $\mathrm{Et}_{3} \mathrm{~N}$-ether) as well as in heterogeneous conditions (basic alumina), and the 2-isoxazolines $\mathbf{1 3 9}$ are formed predominantly as trans- isomers.

Oxidation of the resorcinol derivative 140 with bis-(trifluoroacetoxy)-iodobenzene occurs with concomitant attack of the nitro- group's oxygen to the ring, leading to the spiro-nitronate, 141 (Scheme 33). ${ }^{56}$ Reduction at the nitrogen atom using trimethyl phosphite gives, in high yield, the spiroisoxazoline 142. Since compound 141 contains a dienone group, it can be made to react 
with nucleophiles such as the methoxide anion, leading to the spiro- derivative 143 with satisfactory diastereoselectivity. Catalytic hydrogenation of compound $\mathbf{1 4 3}$ in the presence of $\mathrm{PtCl}_{2}$ generates a primary amine, which by an intramolecular conjugate addition-elimination produces the pyrrolidine derivative $\mathbf{1 4 4}$ with high diastereoselectivity.

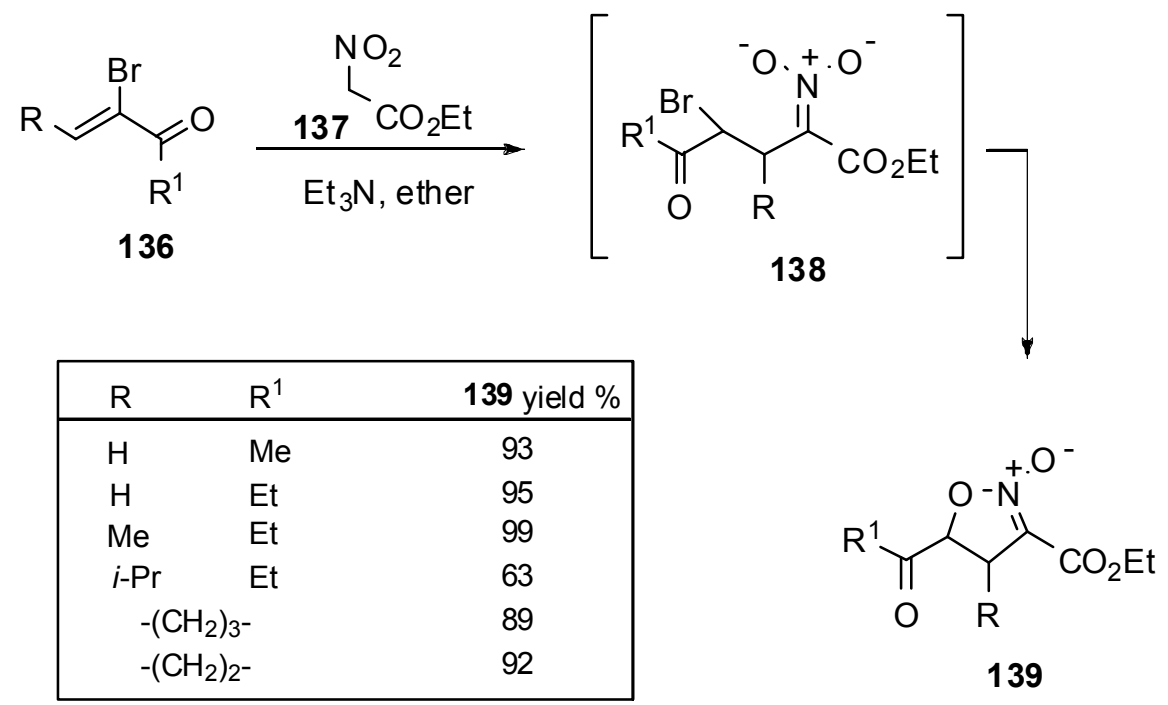

\section{Scheme 32}<smiles>COc1cc(O)ccc1CC(C[OH+])[N+](=O)[O-]</smiles>

140

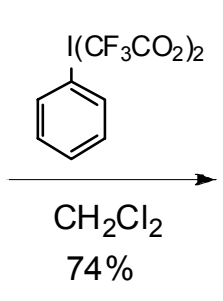

141<smiles>COC1=CC(=O)C=CC12CC(C[OH+])=N[O+]2</smiles>

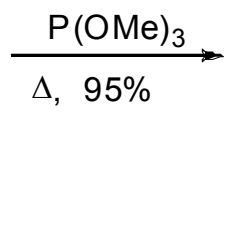

$\mathrm{NaOMe}$ $\mathrm{MeOH}$ $d r=5: 1,68 \%$<smiles>COC1=CC(=O)C[C@H](OC)C12CC(C[OH+])=N[O+]2[O-]</smiles>

143

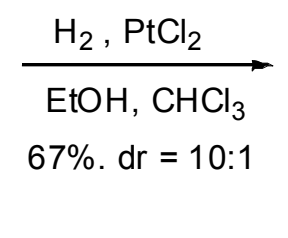

$67 \% . d r=10: 1$<smiles>COC1=CC(=O)C=CC12CC(C[OH+])=NO2</smiles>

142

\section{Scheme 33}<smiles>CO[C@H]1CC(=O)C=C2N[C@H](CO[R16](F)(F)F)C[C@]21O</smiles>

144 
Cyclic nitronates can be also prepared by intramolecular nucleophilic displacement of $\omega$ halo-nitroalkanes. The nature of the product obtained strongly depends upon from the basic system used to generate the nitronate anion and on the halide atom (Scheme 34). ${ }^{57}$ The iodine atom in compound $\mathbf{1 4 5}$ is readily displaced by oxygen in the presence of triethylamine, leading to a cyclic nitronate, 146, which in the presence of alkenes undergoes a 1,3-dipolar cycloaddition. The obtained bicyclo derivative $\mathbf{1 4 7}$ promptly decomposes to the hydroxyethylisoxazoline, 148, that is finally isolated in satisfactory yield. The less reactive 3chloronitropropane, 149, in the presence of DBU, is converted into the nitronate anion that reacts faster with methyl acrylate in a Michael process than in a ring closure, leading to intermediate 150. Cyclization follows, giving compound $\mathbf{1 5 1}$ which is isolated in very good yield.

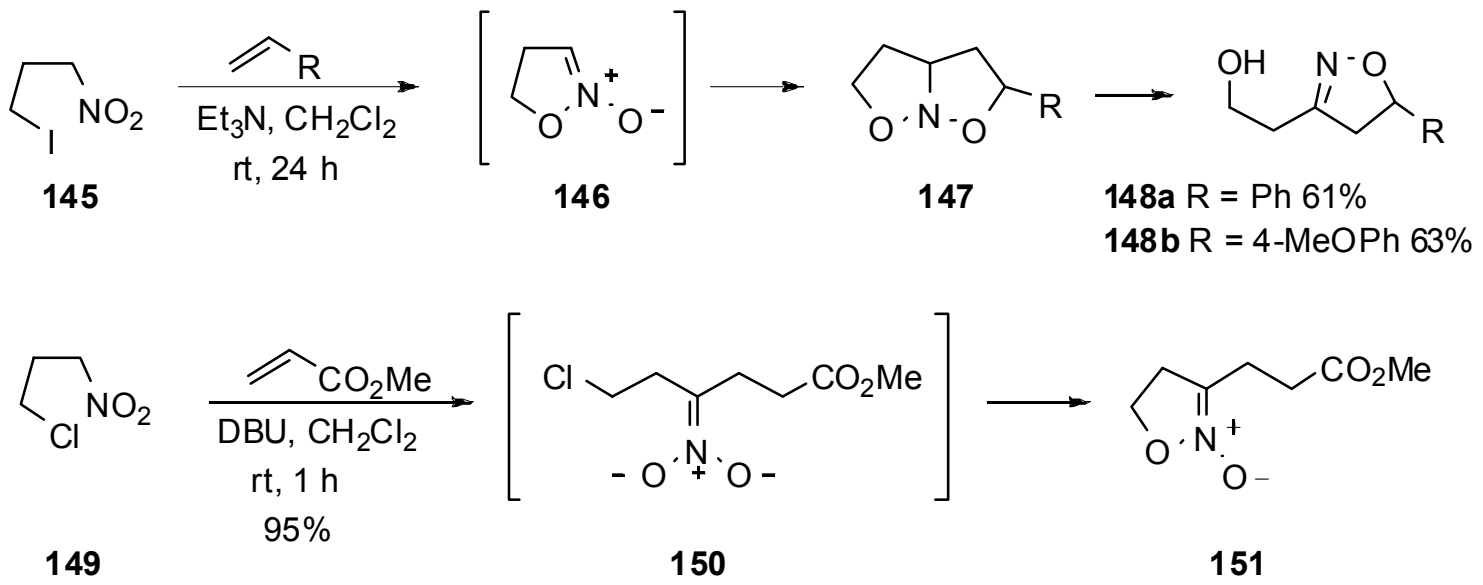

\section{Scheme 34}

A tunable synthesis of isoxazolines and isoxazoles can be realized, starting from activated primary nitro compounds (Scheme 35). ${ }^{58}$ Reaction of the nitro compounds 5 with alkenes leads regioselectively to the isoxazoline $\mathbf{1 5 2}$, while the same process with alkynes produces isoxazoles, 153. In the proposed catalytic cycle the hydrogen-bonded ion pair formed between the nitronate and the protonated base in chloroform undergoes reversible cycloaddition with the dipolarophile, and then the hydrogen-bonded intermediate adduct releases water by reaction with a second nitro-molecule to give the product and the hydrogen-bonded nitronate. The same process can also be carried out on simple primary nitroalkanes, $5\left(\mathrm{R}=\mathrm{Et}, n-\mathrm{Pr}, n-\mathrm{C}_{5} \mathrm{H}_{11}\right)$ provided that 1methylpiperidine is used as a base in the presence of copper (II) acetate. ${ }^{59}$ Nitrile oxides seem not to be involved as intermediates in this process since no furoxans are detected. 

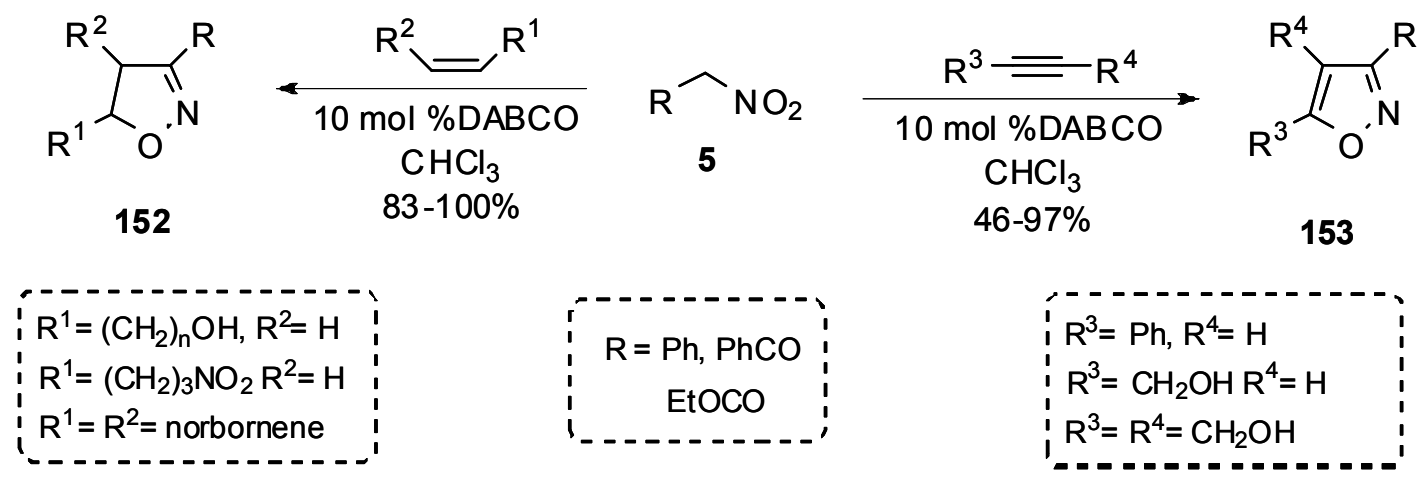

\section{Scheme 35}

Nitrile oxides are usually generated from nitroalkanes by treatment with phenyl isocyanate under basic conditions. ${ }^{54,60}$ Reaction of ketones $\mathbf{1 5 4}$ with cerium(IV) ammonium nitrate leads to nitro- ketones 155 that, under the same conditions, produce nitrile oxides, 156 (Scheme 36). ${ }^{61,62}$ These 1,3-dipoles react with alkenes to give isoxazolines, 157, and with alkynes to give isoxazoles. Particularly, reaction of intermediate nitrile oxides $\mathbf{1 5 6}$ with the alkynyl glycosides 158 affords the isoxazoles $\mathbf{1 5 9}$, which are stable pharmacophores for glycomimetic syntheses. ${ }^{63}$

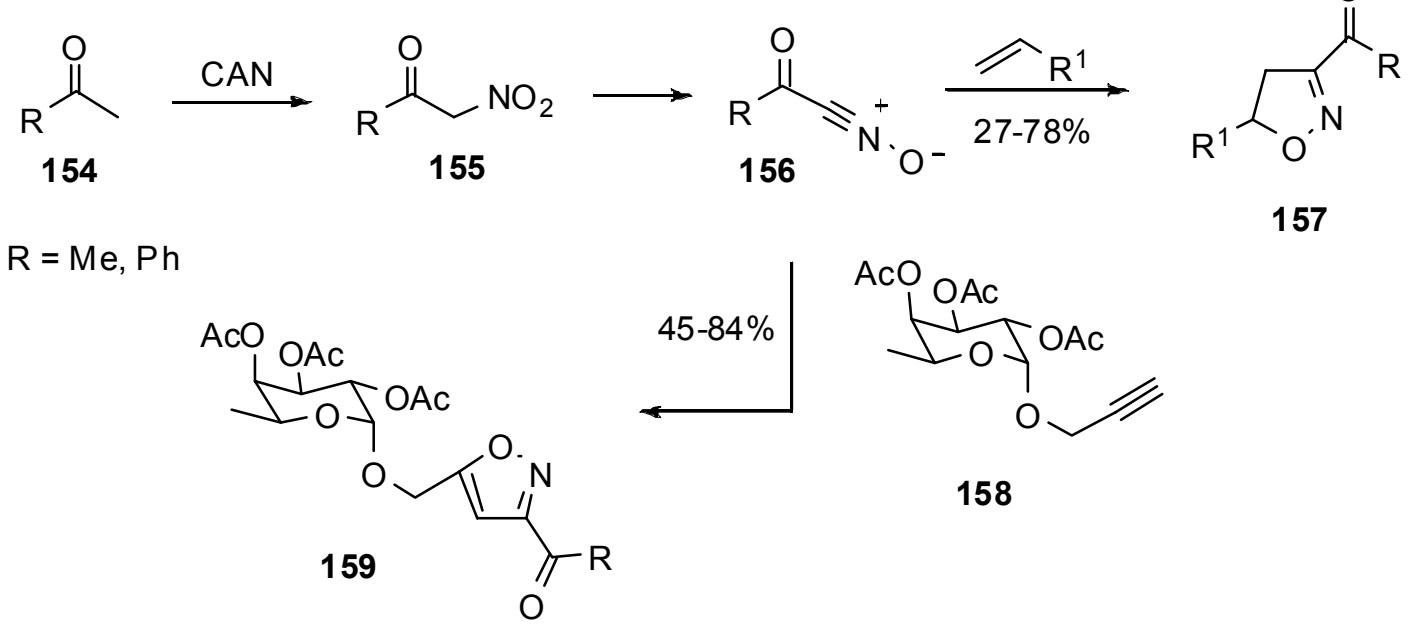

\section{Scheme 36}

\section{Conclusions}

Nitroalkanes are versatile intermediates in organic synthesis since they are readily converted into the corresponding nitronate anions that can serve as a source of stabilized carbanions. Conjugate additions, as well as nitro-aldol reactions using nitronate anions, allow relatively easy carboncarbon bond formation, while the nitro group present in the final product is amenable to further 
synthetic transformations. Reduction of the nitro group into the amino group, or conversion into carbonyl groups, provides the necessary heteroatoms for the construction of heterocyclic derivatives. Lactones and spiroketals are usually prepared by exploiting the nitro- to carbonyl conversion (Nef reaction). Pyrrolidines, lactams and other nitrogenated derivatives are obtained by reduction of the nitro group, followed by cyclization. Finally, nitronate anion- cyclization provides a favorable strategy for the assembly of polyheterocyclic compounds featured by both the nitrogen and oxygen atoms.

\section{Acknowledgements}

Financial support from University of Camerino and MIUR (National Project "Sintesi organiche ecosostenibili mediate da nuovi sistemi catalitici") is gratefully acknowledged.

\section{References}

1. Ballini, R.; Marcantoni, E; Petrini, M. Nitroalkenes as Amination Tools, in Amino Group Chemistry; Ricci, A. Ed.; Wiley-VCH: Weinheim, 2008, p 93.

2. The Chemistry of Amino, Nitroso, Nitro and Related Groups Patai, S., Ed.; Wiley: Chichester, 1996.

3. Ballini, R.; Petrini, M. Tetrahedron 2004, 60, 1017.

4. Ono, N. The Nitro Group in Organic Synthesis; Wiley-VCH: New York, 2001.

5. Seebach, D.; Lehr, F. Angew. Chem., Int. Ed. 1976, 15, 505.

6. Rosini, G. In Comprehensive Organic Synthesis, Trost, B. M. Ed.; Pergamon: Oxford, 1991; Vol. 2, p. 321.

7. Luzzio, F. A. Tetrahedron 2001, 57, 915.

8. Ballini, R.; Bosica, G.; Fiorini, D.; Palmieri, A.; Petrini, M. Chem. Rev. 2005, 105, 933.

9. Berner, O. M.; Tedeschi, L.; Enders, D. Eur. J. Org. Chem. 2002, 1877.

10. Perekalin, V. V.; Lipina, E. S.; Berestovitskaya, V. M.; Efremov, D. A. Nitroalkenes Conjugated Nitro Compounds, Wiley: Chichester, 1994.

11. Barrett, A. G. M. Chem. Soc. Rev. 1991, $20,95$.

12. Ballini, R.; Petrini, M.; Marotta, E. Synth. Commun. 1989, 19, 575.

13. Sarmah, B. K.; Barua, N. C. Tetrahedron 1993, 49, 2253.

14. Ballini, R.; Bosica, G.; Livi, D. Synthesis 2001, 1519.

15. Ballini, R. Synlett 1999, 1009.

16. Ballini, R.; Petrini, M.; Polzonetti, V. Synthesis 1992, 355.

17. Ballini, R.; Barboni, L.; Pintucci, L. Synlett 1997, 1389.

18. Stach, H.; Hesse, M. Tetrahedron 1988, 44, 1573.

19. Cookson, R.C.; Ray, P. S. Tetrahedron Lett. 1982, 23, 3521. 
20. Kalita, D.; Khan, A. T.; Barua, N. C.; Bez, G. Tetrahedron 1999, 55, 5177.

21. McMurry, J. E.; Melton, J. J. Org. Chem. 1973, 38, 4367.

22. Kalita, D.; Khan, A. T.; Saikia, A. K; Bez, G.; Barua, N. C. Synthesis 1998, 975.

23. Aho, J. E.; Pihko, P. M.; Rissa, T. K. Chem. Rev. 2005, 105, 4406.

24. Rosini, G.; Ballini, R.; Petrini, M., Marotta, E. Angew. Chem., Int. Ed. Engl. 1986, 25, 941.

25. Ballini, R.; Petrini, M.; Rosini, G. Tetrahedron 1990, 46, 7531.

26. Ballini, R.; Petrini, M. J. Chem. Soc., Perkin Trans. 1 1992, 3159.

27. Ballini, R.; Bosica, G.; Schaafstra, R. Liebig's Ann. Chem. 1994, 1235.

28. Basavaiah, D.; Rao, J. S. Tetrahedron Lett. 2004, 45, 1621.

29. Błaszczyk, E.; Krawczyk, H.; Janecki, T. Synlett 2004, 2865.

30. Aszodi, J.; Rowlands, D. A.; Mauvais, P.; Collette, P.; Bonnefoy, A.; Lampilas, M. Bioorg. Med. Chem. Lett. 2004, 14, 2489.

31. Felluga, F.; Gombac, V.; Pitacco, G.; Valentin, E. Tetrahedron: Asymmetry 2004, 15, 3323.

32. Mironiuk-Puchalska, E.; Kołaczkowska, E.; Sas, W. Tetrahedron Lett. 2002, 43, 8351.

33. Kuciak, R.; Sas, W. Tetrahedron Lett. 1994, 35, 8647.

34. Domingos, J. L. O.; Lima, E. C.; Dias, A. G.; Costa, P. R. R. Tetrahedron: Asymmetry 2004, $15,2313$.

35. Costa, J. S.; Dias, A. G.; Anholeto, A. L.; Monteiro, M. D.; Patrocinio, V. L.; Costa, P. R. R. J. Org. Chem. 1997, 62, 4002.

36. Ishibashi, H.; Okano, M.; Tamaki, H.; Maruyama, K.; Yakura, T.; Ikeda, M. J. Chem. Soc., Chem. Commun. 1990, 1436.

37. Palomo, C.; Landa, A.; Mielgo, A.; Oiarbide, M.; Puente, A.; Vera, S. Angew. Chem., Int. Ed. 2007, 46, 8431.

38. Mouna, A. M.; Blanchard, P.; Fourrey, J.-L.; Robert-Gero, M. Tetrahedron Lett. 1990, 31, 7003.

39. Desai, M. C.; Lefkowitz, S. L. Bioorg. Med. Chem. Lett. 1993, 3, 2083.

40. Kieß, F.-M.; Poggendorf, P.; Picasso, S.; Jäger, V. Chem. Commun. 1998, 119.

41. Appel, R. Angew. Chem. Int. Ed. 1975, 14, 801.

42. Sankuratri, N.; Janzen, E. G.; West, M. S.; Poyer, J. L. J. Org. Chem. 1997, 62, 1176.

43. Black, D. St. C.; Edwards, G. L.; Evans, R. H.; Keller, P. A.; Laaman, S. M. Tetrahedron 2000, 56, 1889.

44. Nsanzumuhire, C.; Clément, J.-L.; Ouari, O.; Karoui, H.; Finet, J.-P.; Tordo, P. Tetrahedron Lett. 2004, 45, 6385.

45. Vavrecka, M.; Janowitz, A.; Hesse, M. Tetrahedron Lett. 1991, 32, 5543.

46. Vavrecka, M.; Hesse, M. Helv. Chim. Acta 1991, 74, 438.

47. Francke, W.; Schröder, F.; Walter, F.; Sinnwell, V.; Baumann, H.; Kaib, M. Liebig's Ann. Chem. 1995, 965.

48. Petrini, M. Chem. Rev. 2005, 105, 3949.

49. Foresti, E.; Palmieri, G.; Petrini, M.; Profeta, R. Org. Biomol. Chem. 2003, 1, 4275.

50. Marsh, G. P.; Parsons, P. J.; McCarthy, C.; Corniquet, X. G. Org. Lett. 2007, 9, 2613. 
51. Stanetty, P.; Kremslehner, M. Synth. Commun. 1998, 28, 2491.

52. Stanetty, P.; Kremslehner, M.; Mihovilovic, M. D. Tetrahedron Lett. 2000, 41, 1717.

53. Bandini, M.; Piccinelli, F.; Tommasi, S.; Umani-Ronchi, A.; Ventrici, C. Chem. Commun. 2007, 616.

54. Torssell, K. B. G. Nitrile Oxides, Nitrones and Nitronates in Organic Synthesis VCH: New York, 1988.

55. Galli, C.; Marotta, E.; Righi, P.; Rosini, G. J. Org. Chem. 1995, 60, 6624.

56. Marsini, M. A.; Huang, Y.; Van de Water, R. W.; Pettus, T. R. R. Org. Lett. 2007, 9, 3229.

57. Kanemasa, S.; Yoshimiya, T.; Wada, E. Tetrahedron Lett. 1998, 39, 8869.

58. Machetti, F.; Cecchi, L.; Trogu, E.; De Sarlo, F. Eur. J. Org. Chem. 2007, 4352.

59. Cecchi, L.; De Sarlo, F.; Machetti, F. Synlett 2007, 2451.

60. Mukaiyama, T.; Hoshino, T. J. Am. Chem. Soc. 1960, 82, 5339.

61. Itoh, K.; Takahashi, S.; Ueki, T.; Sugiyama, T.; Takahashi, T. T.; Horiuchi, C. A. Tetrahedron Lett. 2002, 43, 7035.

62. Itoh, K.; Horiuchi, C. A. Tetrahedron 2004, 60, 1671.

63. Béha, S.; Giguère, D.; Patnam, R.; Roy, R. Synlett 2006, 1739.

\section{Authors' biographical data}

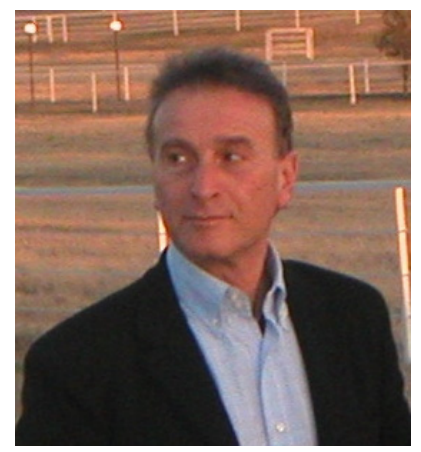

Roberto Ballini obtained the Laurea degree of Chemistry at the University of Camerino, then he moved to the petrochemical Industry (ENI-ANIC in Ravenna). After two years, R.B. began his academic career at the University of Camerino as Research Fellowship, then as Associate Professor and, finally, as full Professor of Organic Chemistry. Presently, R.B. is the Dean of the Faculty of Sciences and Technologies of the University of Camerino. His research interests include a large area of the chemistry of aliphatic nitro compounds, with particular interest to the generation of new carbon-carbon single and double bonds, and the cleavage of carbon-carbon bond from cyclic derivatives. Other special fields of extensive interest concern the study and the application of solid catalysis in the synthesis of fine chemicals, the exploitation of solvent-less reactions, the application of water as solvent in organic transformations, and the development of new eco-sustainable procedures in organic synthesis. 


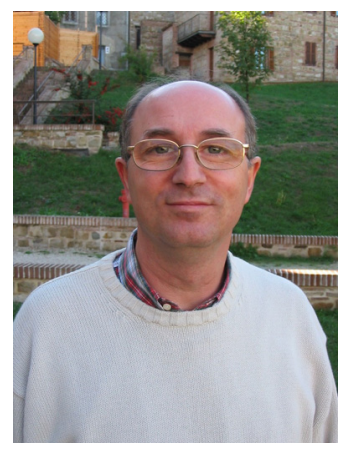

Marino Petrini took his Laurea degree in Chemistry in 1980 (University of Camerino). In 1983 he became Research Associate in organic chemistry at the University of Camerino and during the period 1987-88 he has been visiting scientist at the University of Montreal (Prof. S. Hanessian). In 1992 he was appointed Associate Professor and then (2004) Full Professor in organic chemistry at the University of Camerino. Presently, M.P. is Head of the Department of Chemical Sciences of the University of Camerino. His research interests mainly deal with the following topics: synthesis and reactivity of aliphatic and aromatic nitro compounds; reactivity of organometallic reagents towards carbon and nitrogen electrophiles; synthesis of natural products featured of enhanced biological activity; synthesis and reactivity of imino derivatives. 